\title{
Oxone $^{\circledR}$-Mediated Direct $\alpha$-Hydroxylation of $\beta$-Dicarbonyl Compounds: Racemic Synthesis of Harzialactone A
}

\author{
Marcus M. Sá, ${ }^{*, a}$ Marcos M. Peterle ${ }^{\oplus a}$ and Marcelo V. Marques ${ }^{b}$ \\ ${ }^{a}$ Departamento de Química, Universidade Federal de Santa Catarina, 88040-900 Florianópolis-SC, Brazil \\ ${ }^{b}$ Instituto Federal Catarinense (IFC), Campus Fraiburgo, 89580-000 Fraiburgo-SC, Brazil
}

\begin{abstract}
An environmentally benign method is described for the $\alpha$-hydroxylation of malonates and cyclic analogues in aqueous medium at room temperature under mild conditions, based on the in situ generation of dimethyldioxirane through the combination of acetone and Oxone ${ }^{\circledR}$. This procedure was found to be substrate-dependent and was successfully performed to provide $\alpha$-hydroxylated $\gamma$-lactones. To demonstrate the synthetic potential of this mild $\alpha$-hydroxylation, two different concise routes were developed to synthesize harzialactone $\mathrm{A}$ in the racemic form with a moderate (3:1) diastereomeric ratio.
\end{abstract}

Keywords: harzialactone, $\alpha$-hydroxylation, $\alpha$-hydroxy malonates, $\alpha$-hydroxy- $\gamma$-lactone, Oxone $^{\circledR}$

\section{Introduction}

Many natural products and pharmaceuticals contain the $\alpha$-hydroxy- $\beta$-dicarbonyl framework as a common structural feature. $\alpha$-Hydroxy- $\beta$-dicarbonyl compounds are also useful synthetic building blocks for the synthesis of a variety of biologically active substances, including naturally occurring carbocycles and heterocycles. ${ }^{1,2}$ The most common strategy to prepare $\alpha$-hydroxy- $\beta$-dicarbonyl compounds involves the direct $\alpha$-hydroxylation of the parent $\beta$-dicarbonyls (or their corresponding enolates and analogues) using different oxidizing agents such as peroxides, ${ }^{3}$ peroxyacids,${ }^{4,5}$ oxaziridines ${ }^{6}$ and $\mathrm{O}_{2},{ }^{7}$ usually in the presence of appropriate catalysts and additives..$^{8-12}$ Despite their recognized applicability, these methods are associated with a number of disadvantages, such as the use of expensive reagents and catalysts, the need to handle and dispose of toxic chemicals and byproducts, the generation of large amounts of residues, and/or the limited substrate scope.

Oxone $^{\circledR}$ (potassium peroxymonosulfate) is a safe and inexpensive oxidizing reagent of widespread application, including the oxidation of acetone to give dimethyldioxirane (DMD), an unstable oxidant employed in the $\alpha$-hydroxylation of $\beta$-dicarbonyl compounds. ${ }^{13,14}$ However, DMD itself is reluctant to oxidize $\alpha$-substituted malonates, with high conversions to the corresponding

*e-mail: marcus.sa@ufsc.br $\alpha$-hydroxy- $\beta$-dicarbonyls being achieved only in the presence of a nickel catalyst. ${ }^{15}$ To circumvent the tedious preparation of DMD solutions and the risks associated with their handling, Zhang and co-workers ${ }^{16}$ reported the direct use of Oxone ${ }^{\circledR}$ for the $\alpha$-hydroxylation of a great variety of cyclic $\beta$-keto esters, $\beta$-keto amides, and $\beta$-diketones in aqueous medium at $60{ }^{\circ} \mathrm{C}$. However, simple diesters such as malonates proved ineffective as substrates. On the other hand, treating $\beta$-dicarbonyl compounds with a combination of $\mathrm{Oxone}^{\circledR}$ and $\mathrm{AlCl}_{3}$ led to 1,2-diketones through unexpected oxidative cleavage. ${ }^{17}$ As far as we are aware, there is no precedent for the preparation of $\alpha$-hydroxy malonates using $\mathrm{Oxone}^{\circledR}$ as the oxidizing agent.

During studies involving the base-mediated epoxidation of the $\gamma, \delta$-unsaturated malonate $1 \mathbf{a}$ with Oxone ${ }^{\circledR}$, en route to functionalized cyclopropanecarboxamides ${ }^{18}$ and $\gamma$-lactones of the catechin family, ${ }^{19}$ we found that epoxide $2 \mathrm{a}$ could be efficiently prepared in an aqueous biphasic system, while the $\alpha$-hydroxylated epoxide 3a was the major product under homogeneous conditions (Scheme 1). Due to the synthetic potential of this transformation, we conducted further studies to establish the scope and limitation of the Oxone $^{\circledR}$-mediated $\alpha$-hydroxylation of malonates.

In this paper, we report an environmentally benign route to $\alpha$-hydroxy malonates through a mild Oxone ${ }^{{ }_{-}}$ mediated $\alpha$-hydroxylation of malonates and analogues in aqueous medium under slightly alkaline conditions (phosphate buffer, $\mathrm{pH} 8$ ) at room temperature. These simple conditions were successfully employed in a flexible 
strategy for the racemic synthesis of both diastereoisomers of harzialactone A (4a, Scheme 1), an $\alpha$-hydroxy- $\gamma$-lactone of marine origin which exhibits cytotoxic activity. ${ }^{20-24}$

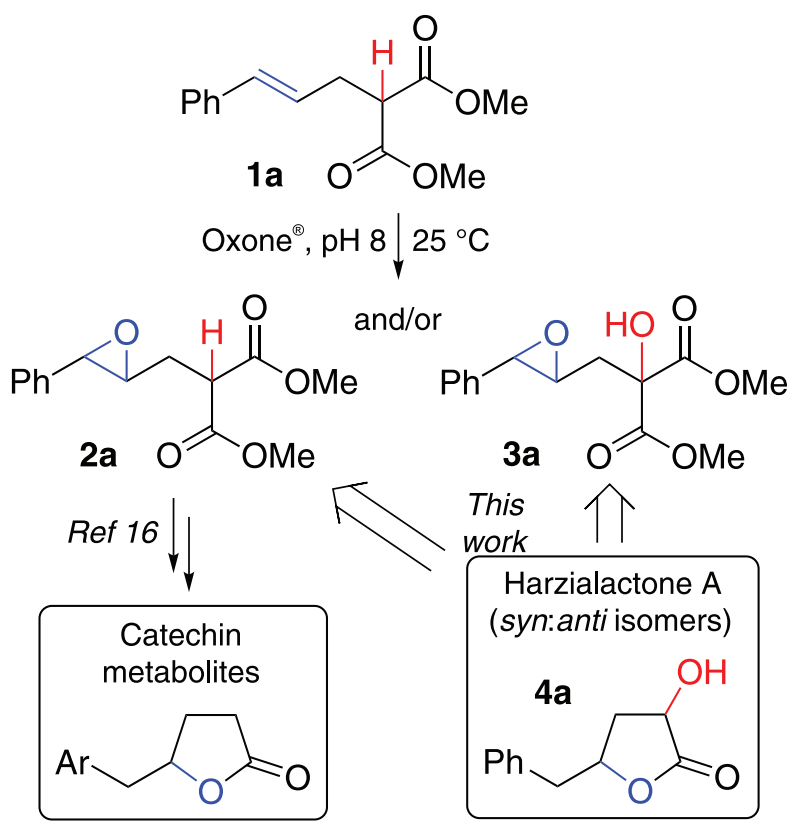

Scheme 1. Previous work on the synthesis of $\gamma$-lactones and current research on the Oxone ${ }^{\circledast}$ mediated $\alpha$-hydroxylation.

\section{Results and Discussion}

Firstly, the preparation of the $\alpha$-hydroxylated epoxide 3a from the domino epoxidation/ $\alpha$-hydroxylation of $\gamma, \delta$-unsaturated malonate 1 with Oxone ${ }^{\circledR}$ in aqueous acetone was optimized. While the use of a EtOAc: $\mathrm{H}_{2} \mathrm{O}$ biphasic system was efficient to selectively produce epoxide $\mathbf{2 a},{ }^{18,19}$ the homogeneous condition obtained in the absence of ethyl acetate (EtOAc) led to the almost exclusive formation of $\alpha$-hydroxylated epoxide 3a from 1a (Scheme 2).

In both cases, the mild alkaline medium employed (phosphate buffer, $\mathrm{pH}$ ca. 8) was crucial to the success of the oxidation. In fact, running the reaction in the presence of carbonated bases such as $\mathrm{NaHCO}_{3}$ or $\mathrm{K}_{2} \mathrm{CO}_{3}(\mathrm{pH}>8)$ led to mixtures of $\mathbf{2 a}$ and $\mathbf{3 a}$, along with side products, due to a partial loss of chemoselectivity under more basic conditions. As expected, treating epoxide $\mathbf{2 a}$ with Oxone ${ }^{\circledR}$ under homogeneous conditions gave cleanly the $\alpha$-hydroxylated epoxide $\mathbf{3 a}$ in good isolated yield, thus supporting the intermediacy of $\mathbf{2 a}$ in the domino epoxidation/ $\alpha$-hydroxylation from $\gamma, \delta$-unsaturated malonate 1a. Similar results were observed for the related unsaturated malonate $\mathbf{1 b}$, which was selectively transformed into the desired epoxide $\mathbf{2} \mathbf{b}$ and then to the $\alpha$-hydroxylated epoxide $\mathbf{3 b}$ (Scheme 2 ).

The remarkable dependence of the reactivity profile on the solvent used is related to whether the unsaturated malonate $\mathbf{1}$, as well as the preformed epoxide $\mathbf{2}$, are intimately exposed to the alkaline medium. In the particular case of the homogeneous conditions (i.e., in the absence of EtOAc), the basic medium favors the initial deprotonation of malonates to generate stabilized enolates, which are the proposed intermediates for the subsequent $\alpha$-hydroxylation. ${ }^{15}$ Conversely, the use of a biphasic system due to the presence of EtOAc as a cosolvent segregates the substrate $\mathbf{1}$ and the product $\mathbf{2}$ in the organic phase, while the basic species (phosphate and related ions) are maintained solvated in the aqueous phase, thus avoiding the extensive enolization of malonates and the concurrent overoxidation to $3 .^{25}$

Based on the above results, the scope and limitations of the $\alpha$-hydroxylation of malonates were studied from a synthetic perspective using a combination of Oxone ${ }^{\circledR}$ and acetone in a slightly alkaline phosphate buffer. Under these homogeneous conditions, the unsubstituted malonates $\mathbf{5 a}, \mathbf{b}$ were rapidly consumed in a few minutes to generate the corresponding $\alpha$-hydroxylated malonates $\mathbf{6 a}, \mathbf{b}$ (Scheme 3 ).

A dihydroxylated malonate 7 was also observed after prolonged reaction times, possibly due to overoxidation of the preformed product $\mathbf{6}$. The relatively high solubility of hydroxylated malonates $\mathbf{6}$ in water caused extensive loss of mass during the work-up and purification steps, leading
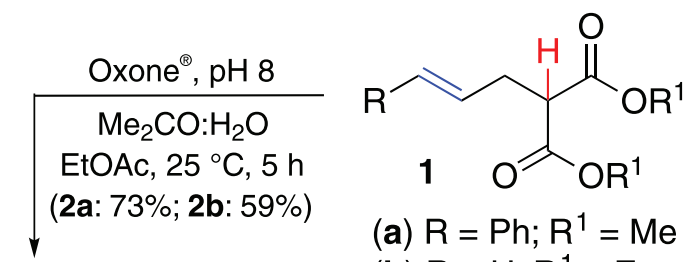

(a) $\mathrm{R}=\mathrm{Ph} ; \mathrm{R}^{1}=\mathrm{Me}$

(b) $\mathrm{R}=\mathrm{H} ; \mathrm{R}^{1}=\mathrm{Et}$<smiles>[R]C1OC1CC(C(=O)O)C(=O)OCC</smiles>

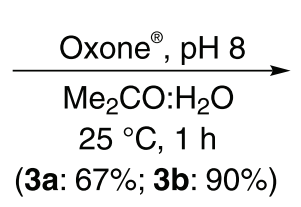

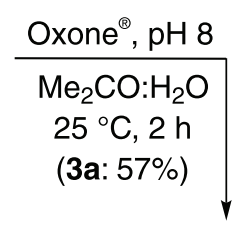

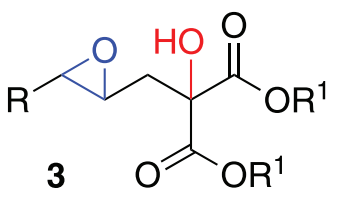

Scheme 2. Domino epoxidation/ $\alpha$-hydroxylation of $\gamma, \delta$-unsaturated malonates 1 with Oxone ${ }^{\circledR}$ in aqueous acetone. 


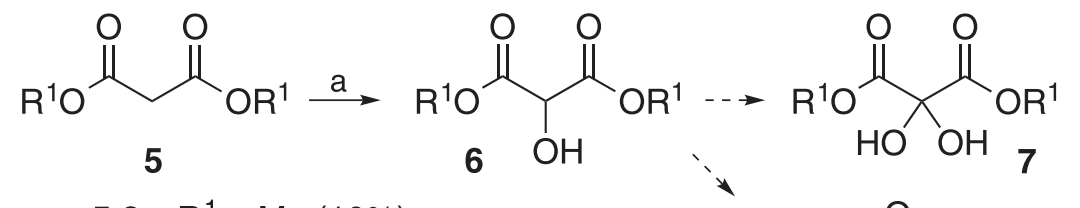

5,6a: $R^{1}=\operatorname{Me}(10 \%)$

5,6b: $R^{1}=$ Et $(33 \%)$

5,6c: $R^{1}=\operatorname{Bn}(56 \%)$

Condition: a. Oxone ${ }^{\oplus}, \mathrm{pH} 8$, $\mathrm{Me}_{2} \mathrm{CO}: \mathrm{H}_{2} \mathrm{O}, 25^{\circ} \mathrm{C}, 15-90 \mathrm{~min}$<smiles>O=C(OCc1ccccc1)C1OC(=O)C(C(=O)OCc2ccccc2)C(=O)O1</smiles><smiles>[R]CC(C(=O)OCC)C(=O)OCC</smiles>

$9 a R=M e ; 9 b R=P h$

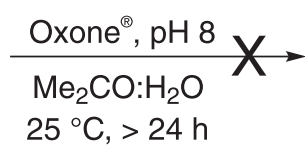<smiles>[R]CC(O)(C(=O)OCC)C(=O)OCC</smiles>

$10 \mathrm{a} R=\mathrm{Me} ; 10 \mathrm{~b} \mathrm{R}=\mathrm{Ph}$

Scheme 3. Scope and limitations of the $\alpha$-hydroxylation.

to low isolated yields (10-33\%) for the expected products. This was not the case for the more hydrophobic dibenzyl $\alpha$-hydroxymalonate (6c, Scheme 3 ), which was readily prepared from the related dibenzyl ester $\mathbf{5 c}$ in good yield after a conventional aqueous work-up. However, a side product, which was tentatively assigned by ${ }^{1} \mathrm{H}$ nuclear magnetic resonance (NMR) as the dimeric adduct 8 (10$20 \%$, see Experimental section) was also formed as a nonseparable contaminant.

In contrast to the high propensity of $\gamma, \delta$-epoxide malonates $\mathbf{2}$ and unsubstituted malonates $\mathbf{5}$ to undergo $\alpha$-hydroxylation with Oxone under homogeneous conditions, the $\alpha$-substituted malonates $9 \mathbf{a}$ and $\mathbf{9 b}$ (Scheme 3) were very reluctant to be oxidized, with negligible conversions (10-15\%) being observed even after running the reaction for prolonged periods ( $>24 \mathrm{~h}$ ) or using a higher excess of the oxidant ( $>2$ equiv). This limited reactivity of malonates $\mathbf{9 a}, \mathbf{b}$ is possibly related to the lower $\alpha-\mathrm{H}$ acidity due to the electron-donating effect displayed by the $\alpha$-alkyl groups, which is not favorable to the generation of the reactive enolate involved in the $\alpha$-hydroxylation. ${ }^{15}$ These combined results strongly indicate that the $\alpha$-hydroxylation of $\gamma, \delta$-epoxide malonates $\mathbf{2}$ is favored due to the higher $\alpha-\mathrm{H}$ acidity, which is related to the electronwithdrawing effect exerted by the remote oxirane group.

As a proof of concept, we investigated the $\alpha$-hydroxylation of $\alpha$-carboxy- $\gamma$-lactone 11 , which is a cyclic malonate containing electronegative groups (ring oxygen and exo-hydroxyl) in remote positions that should enhance the $\alpha-\mathrm{H}$ acidity and, consequently, favor the oxidation (Scheme 4). The synthesis of the starting $\gamma$-lactone $\mathbf{1 1}$ (as a 2:1 mixture of diastereoisomers) was readily achieved through a Lewis acid-mediated rearrangement ${ }^{26}$ of epoxide $\mathbf{2 a}$ under microwave irradiation.<smiles>COC(=O)C(CC1OC1c1ccccc1)C(=O)OC</smiles><smiles>O=C1OC([C@H](O)c2ccccc2)C[C@H]1O[As]</smiles>

Scheme 4. Synthesis of $\alpha, \delta$-dihydroxy- $\gamma$-lactones $\mathbf{1 2}$ and $\mathbf{1 3}$ from $\mathbf{2 a}$. 
As expected, the base-mediated $\alpha$-hydroxylation of $\mathbf{1 1}$ with Oxone ${ }^{\circledR}$ under homogeneous conditions occurred rapidly and cleanly to give a diastereoisomeric mixture of $\alpha, \delta$-dihydroxy$\gamma$-lactones 12 in a 2:1 ratio. Subsequent microwave-assisted Krapcho decarboxylation of $\gamma$-lactone $\mathbf{1 2}$ was readily achieved to furnish the corresponding dihydroxylated lactone $\mathbf{1 3}$ as a diastereomeric pair. The epimers 13-syn and 13-anti could be carefully separated by chromatography, although in low isolated yields, and were fully characterized (see Experimental section).

To demonstrate further the synthetic and strategic potential of applying this mild $\alpha$-hydroxylation of activated malonates to prepare valuable compounds, we designed a concise racemic synthesis of harzialactone A (4a) by two interrelated strategies starting with epoxide $\mathbf{2 a}$ as the common precursor (Scheme 5).

In the first route, the $\alpha$-hydroxylated epoxide 3a was employed as an advanced intermediate, which was obtained by the $\alpha$-hydroxylation of $\mathbf{2 a}$ or, alternatively, from the $\gamma, \delta$-unsaturated malonate 1a through the domino epoxidation/ $\alpha$-hydroxylation process, as described above. Thus, the palladium-catalyzed hydrogenolysis of the benzylic $\mathrm{C}-\mathrm{O}$ bond in $\mathbf{3 a}$ led directly to the $\alpha$-hydroxylated lactone 16, possibly through the intermediacy of the expected $\gamma$-hydroxy malonate $\mathbf{1 7}$, in $47 \%$ yield. However, the observed diastereoselectivity for the cyclization was low, giving lactone $\mathbf{1 6}$ as a 1.7:1 mixture of epimers. Subsequent decarboxylation of $\mathbf{1 6}$ under Krapcho conditions, as described above for the dihydroxylated lactone $\mathbf{1 2}$, led to the desired $\gamma$-lactone $\mathbf{4}$ as the sole product in $45 \%$ yield (2:1 syn:anti mixture of diastereoisomers). The relative syn:anti stereochemistry of each diastereomer of $\mathbf{4}$ was assigned based on the NMR data described in the literature, ${ }^{23}$ wherein the carbinolic $\mathrm{H}-\alpha$ hydrogen for the 4-anti isomer is shifted upfield (4.02 ppm) relative to the 4-syn epimer (4.5-4.6 ppm); conversely, $\mathrm{H}-\gamma$ for the 4-anti isomer is shifted downfield (ca. $4.9 \mathrm{ppm}$ ) relative to 4 -syn (4.5-4.6 ppm).

In the second designed strategy for the synthesis of harzialactone A (4, Scheme 5), the known $\gamma$-hydroxy malonate $\mathbf{1 4}$ (which was readily obtained from the hydrogenolysis of epoxide 3a in excellent yield) ${ }^{19}$ underwent a Lewis acid-mediated cyclization to the corresponding $\alpha$-carboxy- $\gamma$-lactone $\mathbf{1 5}$ in high yield but with poor diastereoselectivity (ca. 1.1:1). Nevertheless, the subsequent $O x{ }{ }^{\circledR}{ }^{-}$-mediated $\alpha$-hydroxylation of $\mathbf{1 5}$ proved to be straightforward, due to not only the high yields and simplicity of the method but also the amplification of

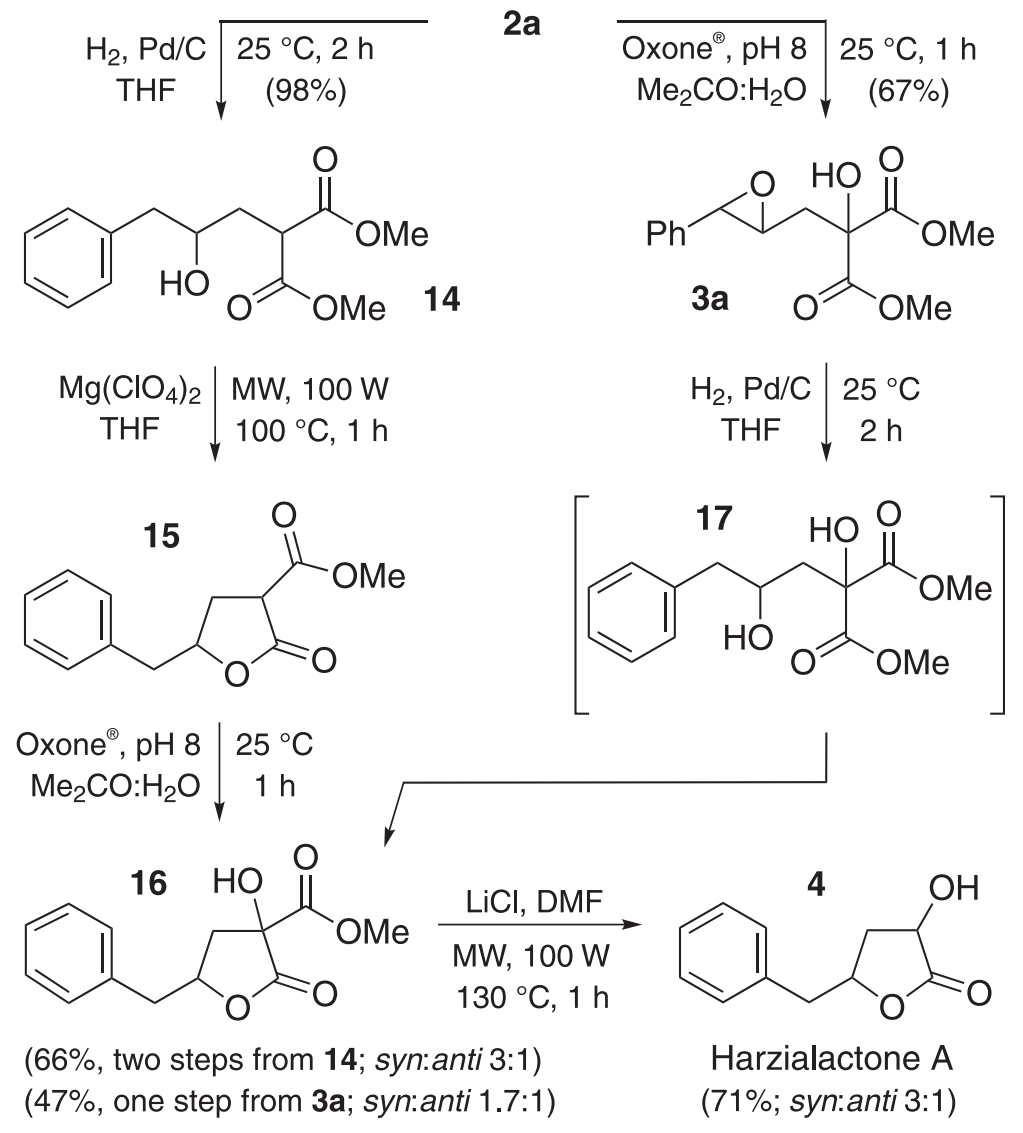

Scheme 5. Two strategies for the racemic synthesis of harzialactone A (4a) starting with epoxide $\mathbf{2 a}$. 
diastereoselectivity (3:1 syn:anti). This improvement in the stereoselectivity from the starting lactone $\mathbf{1 5}$ to the $\alpha$-hydroxylated derivative $\mathbf{1 6}$ is possibly related to the reaction mechanism involving the formation of a planar enolate with distinct pro-chiral faces for the approaching of the oxidizing agent $\mathrm{DMD},{ }^{15}$ but at this point no definitive conclusions could be drawn. Finally, the microwaveassisted Krapcho decarboxylation of $\mathbf{1 6}$ led to the target $\gamma$-lactone 4 as a 3:1 syn:anti mixture of diastereomers (Scheme 5), indicating that the diastereoselectivity gained during the $\alpha$-hydroxylation was maintained after the removal of the methoxycarbonyl group.

\section{Conclusions}

In summary, we have reported herein a simple methodology for the $\alpha$-hydroxylation of malonates, which showed dependence on the electronic character of the $\alpha$-substituent present in the starting malonates. Furthermore, we demonstrated that $\alpha$-carboxy- $\gamma$-lactones are useful substrates for the $\alpha$-hydroxylation and this strategy was successfully employed in the racemic synthesis of both diastereoisomers of harzialactone A, which could be isolated and fully characterized. Although the diastereomeric ratio is dependent upon the synthetic route chosen to obtain harzialactone $\mathrm{A}$, further investigation should be undertaken to unfold the mechanistic aspects of the $\alpha$-hydroxylation and work along these lines is underway.

\section{Experimental}

\section{General methods}

Melting points were determined using a hot plate apparatus and are uncorrected. Infrared spectra were acquired with a Fourier transform infrared (FTIR) spectrometer (range 4000-400 $\mathrm{cm}^{-1}$ ) using $\mathrm{KBr}$ for solids and film for liquid samples. ${ }^{1} \mathrm{H}$ NMR spectra were recorded at 400 or at $200 \mathrm{MHz}$ and ${ }^{13} \mathrm{C}$ NMR spectra (fully decoupled) were recorded at 100 or at $50 \mathrm{MHz}$. Splitting patterns are designated as s (singlet), br s (broad singlet), d (doublet), dd (doublet of doublet), ddd (doublet of doublet of doublet), $\mathrm{t}$ (triplet), dt (doublet of triplet), appdt (apparent doublet of triplet), m (multiplet). Coupling constants $(J)$ are measured in hertz $(\mathrm{Hz})$. Chemical shifts were presented in parts per million ( $\mathrm{ppm}, \delta$ ) relative to tetramethylsilane (TMS) (at $0.00 \mathrm{ppm}$ ) or $\mathrm{CDCl}_{3}$ (at $7.26 \mathrm{ppm}$ for ${ }^{1} \mathrm{H} \mathrm{NMR}$ and at $77.16 \mathrm{ppm}$ for ${ }^{13} \mathrm{C}$ NMR) as the internal standard. Column chromatography was performed using silica gel (70-230 mesh) and hexane/ethyl acetate as the eluent. Thin layer chromatography (TLC) analysis was performed in silica gel plates. The electrospray-ionization quadrupole time-of-flight (ESI-QTOF) mass spectrometer was operated in the positive ion mode at $4.5 \mathrm{kV}$ and at a desolvation temperature of $180^{\circ} \mathrm{C}$. The standard electrospray ion (ESI) source was used to generate the ions. The instrument was calibrated in the range $m / z$ 50-3000 using a calibration standard (low concentration tuning mix solution) and data were processed with the aid of computer software. Microwave-assisted reactions were performed in $10 \mathrm{~mL}$ sealed tubes in a monomode microwave CEM Explorer reactor instrument with infrared temperature monitoring and a noninvasive pressure transducer. All chemicals were of reagent grade and were used as received.

\section{Procedures}

Typical procedure for the synthesis of epoxides

To a round-bottomed flask containing alkene $\mathbf{1}^{18}$ $(1.0 \mathrm{mmol})$, ethyl acetate $(10 \mathrm{~mL})$, acetone $(5.0 \mathrm{~mL})$ and phosphate buffer $\left(1.0 \mathrm{~mol} \mathrm{~L}-1 \mathrm{~K}_{2} \mathrm{HPO}_{4} / \mathrm{KH}_{2} \mathrm{PO}_{4}, \mathrm{pH} 8\right.$, $10 \mathrm{~mL}$ ), under magnetic stirring, was added a solution of Oxone $^{\circledR}(1.3 \mathrm{mmol}$ for $\mathbf{1 a}$ or $1.5 \mathrm{mmol}$ for $\mathbf{1 b})$ in water $(5.0 \mathrm{~mL})$ over a period of $1 \mathrm{~h}$. The reaction mixture was stirred until TLC (hexane/EtOAc, 80:20, v/v) showed completion of the reaction (see below). The insoluble solid was separated by filtration under reduced pressure and washed with EtOAc. The filtrate was washed with $1.0 \mathrm{~mol} \mathrm{~L}^{-1} \mathrm{Na}_{2} \mathrm{~S}_{2} \mathrm{O}_{3}$ and brine, dried over anhydrous $\mathrm{Na}_{2} \mathrm{SO}_{4}$, and concentrated under reduced pressure to give the epoxides as pale yellow oil. The crude mixture was purified by silica gel chromatography (hexane:EtOAc, 80:20, v/v) to provide epoxides $\mathbf{2 a}$ and $\mathbf{2 b}$.

Methyl 4,5-epoxy-2-(methoxycarbonyl)-5-phenylpentanoate $(2 a)^{18}$

Pale yellow oil; $1 \mathrm{~h}$; yield $193 \mathrm{mg}$ (73\%); IR (KBr) $v / \mathrm{cm}^{-1} 3002,2955,1736,1436,1238,1158,881,755$, 700, 553; ${ }^{1} \mathrm{H}$ NMR $\left(200 \mathrm{MHz}, \mathrm{CDCl}_{3}\right) \delta$ 7.35-7.29 (m, $3 \mathrm{H}), 7.26-7.21(\mathrm{~m}, 2 \mathrm{H}), 3.77(\mathrm{~s}, 3 \mathrm{H}), 3.76(\mathrm{~s}, 3 \mathrm{H}), 3.67(\mathrm{~d}$, $J 2.0 \mathrm{~Hz}, 1 \mathrm{H}), 3.65(\mathrm{dd}, J 8.8,5.8 \mathrm{~Hz}, 1 \mathrm{H}), 3.06$ (ddd, $J 6.4$, 4.8, $2.0 \mathrm{~Hz}, 1 \mathrm{H}), 2.41$ (ddd, J 14.2, 8.8, $4.8 \mathrm{~Hz}, 1 \mathrm{H}), 2.19$ (appdt, $J 14.2,6.2 \mathrm{~Hz}, 1 \mathrm{H}) ;{ }^{13} \mathrm{C} \mathrm{NMR}\left(100 \mathrm{MHz}, \mathrm{CDCl}_{3}\right)$ $\delta 169.3(\mathrm{C}), 169.2(\mathrm{C}), 136.9(\mathrm{C}), 128.5(2 \times \mathrm{CH}), 128.3$ $(\mathrm{CH}), 125.6(2 \times \mathrm{CH}), 60.1(\mathrm{CH}), 58.9(\mathrm{CH}), 52.9\left(\mathrm{CH}_{3}\right)$, $52.8\left(\mathrm{CH}_{3}\right), 48.5(\mathrm{CH}), 31.6\left(\mathrm{CH}_{2}\right)$.

\section{Ethyl 4,5-epoxy-2-(ethoxycarbonyl)pentanoate (2b) ${ }^{18}$}

Colorless oil; $14 \mathrm{~h}$; yield $127 \mathrm{mg}$ (59\%); IR (KBr) $\mathrm{v} / \mathrm{cm}^{-1}$ 2986, 2939, 1748, 1732, 1446, 1371, 1260, 1238, 1179, 1156, 1030, 861; ${ }^{1} \mathrm{H}$ NMR (400 MHz, $\mathrm{CDCl}_{3}$ ) 
$\delta 4.25-4.20(\mathrm{~m}, 4 \mathrm{H}), 3.54(\mathrm{dd}, J 8.4,6.2 \mathrm{~Hz}, 1 \mathrm{H}), 3.03-3.01$ $(\mathrm{m}, 1 \mathrm{H}), 2.77(\mathrm{t}, J 4.5 \mathrm{~Hz}, 1 \mathrm{H}), 2.52(\mathrm{dd}, J 4.5,2.5 \mathrm{~Hz}$, $1 \mathrm{H}), 2.25$ (ddd, $J 14.0,8.4,4.4 \mathrm{~Hz}, 1 \mathrm{H}), 2.00$ (dt, $J 14.0$, $6.2 \mathrm{~Hz}, 1 \mathrm{H}), 1.30-1.26(\mathrm{~m}, 6 \mathrm{H}) ;{ }^{13} \mathrm{C}$ NMR $(100 \mathrm{MHz}$, $\left.\mathrm{CDCl}_{3}\right) \delta 168.7(\mathrm{C}), 168.6(\mathrm{C}), 61.44\left(\mathrm{CH}_{2}\right), 61.41\left(\mathrm{CH}_{2}\right)$, $49.6(\mathrm{CH}), 48.8(\mathrm{CH}), 47.0\left(\mathrm{CH}_{2}\right), 31.5\left(\mathrm{CH}_{2}\right), 13.9\left(\mathrm{CH}_{3}\right)$, $13.8\left(\mathrm{CH}_{3}\right)$.

General procedure for the $\alpha$-hydroxylation of malonates and $\gamma$-lactones

To a round-bottomed flask containing the corresponding 1,3-dicarbonyl compound $(1.0 \mathrm{mmol})$, acetone $(5.0 \mathrm{~mL})$ and phosphate buffer $\left(1.0 \mathrm{~mol} \mathrm{~L}^{-1} \mathrm{~K}_{2} \mathrm{HPO}_{4} / \mathrm{KH}_{2} \mathrm{PO}_{4}, \mathrm{pH} 8\right.$, $10 \mathrm{~mL}$ ), under magnetic stirring, was added a solution of Oxone ${ }^{\circledR}(921 \mathrm{mg}, 1.5 \mathrm{mmol})$ in water $(5.0 \mathrm{~mL})$ over a period of $1 \mathrm{~h}$. The reaction was monitored through TLC (hexane:EtOAc, 70:30, v/v) until completion $(0.5-3 \mathrm{~h}$, see below). The insoluble solid was separated by filtration under reduced pressure and washed with EtOAc. The filtrate was washed with $1.0 \mathrm{~mol} \mathrm{~L}^{-1} \mathrm{Na}_{2} \mathrm{~S}_{2} \mathrm{O}_{3}$ and brine, dried over anhydrous $\mathrm{Na}_{2} \mathrm{SO}_{4}$, and concentrated under reduced pressure. The crude mixture was purified by silica gel chromatography (hexane:EtOAc, 70:30, v/v) to give the corresponding hydroxylated product.

Methyl 4,5-epoxy-2-hydroxy-2-(methoxycarbonyl)-5-phenylpentanoate (3a)

\section{From epoxide 2a}

Pale yellow oil; $1 \mathrm{~h}$; yield $188 \mathrm{mg}(67 \%)$; IR (KBr) $\mathrm{v} / \mathrm{cm}^{-1} 3482,3008,2957,1744,1438,1287,1228,1150$, $883,748,700 ;{ }^{1} \mathrm{H}$ NMR $\left(400 \mathrm{MHz}, \mathrm{CDCl}_{3}\right) \delta$ 7.34-7.22 (m, $5 \mathrm{H}), 4.07\left(\mathrm{~s}, 1 \mathrm{H}\right.$, exchange with $\left.\mathrm{D}_{2} \mathrm{O}\right), 3.84(\mathrm{~s}, 3 \mathrm{H}), 3.81(\mathrm{~s}$, $3 \mathrm{H}), 3.68$ (d, $J 2.0 \mathrm{~Hz}, 1 \mathrm{H}), 3.16$ (ddd, $J 6.6,4.6,2.0 \mathrm{~Hz}$, 1H), 2.49 (dd, $J 14.4,4.6,1 \mathrm{H}), 2.39$ (dd, $J 14.4,6.6 \mathrm{~Hz}$, $1 \mathrm{H}) ;{ }^{13} \mathrm{C}$ NMR $\left(100 \mathrm{MHz}, \mathrm{CDCl}_{3}\right) \delta 170.8(\mathrm{C}), 170.2(\mathrm{C})$, $136.9(\mathrm{C}), 128.5(2 \times \mathrm{CH}), 128.3(\mathrm{CH}), 125.7(2 \times \mathrm{CH})$, $77.4(\mathrm{C}), 58.5(\mathrm{CH}), 57.9(\mathrm{CH}), 53.8\left(\mathrm{CH}_{3}\right), 53.6\left(\mathrm{CH}_{3}\right)$, $37.8\left(\mathrm{CH}_{2}\right)$; high-resolution mass spectrometry (HRMS) (ESI) $m / z$, calcd. for $\mathrm{C}_{14} \mathrm{H}_{16} \mathrm{O}_{6} \mathrm{Na}^{+}[\mathrm{M}+\mathrm{Na}]^{+}: 303.0839$; found: 303.0845 .

From alkene 1a through a one-pot epoxidation/ $\alpha$ hydroxylation process

To a round-bottomed flask containing alkene 1a (248 $\mathrm{mg}, 1.0 \mathrm{mmol})$, acetone $(5.0 \mathrm{~mL})$ and phosphate buffer (1.0 mol L-1 $\mathrm{K}_{2} \mathrm{HPO}_{4} / \mathrm{KH}_{2} \mathrm{PO}_{4}, \mathrm{pH} 8,10 \mathrm{~mL}$ ), under magnetic stirring, was added a solution of Oxone ${ }^{\circledR}(921 \mathrm{mg}$, $1.5 \mathrm{mmol})$ in water $(5.0 \mathrm{~mL})$ over a period of $1 \mathrm{~h}$. After stirring for an additional $1 \mathrm{~h}$, a second solution of Oxone ${ }^{\circledR}$
(1.5 mmol in $5.0 \mathrm{~mL}$ of $\mathrm{H}_{2} \mathrm{O}$ ) was slowly added during $1 \mathrm{~h}$ and the resulting mixture was stirred for an additional $1.5 \mathrm{~h}$. Next, the insoluble solid was separated by filtration under reduced pressure and washed with EtOAc. The filtrate was washed with $1.0 \mathrm{~mol} \mathrm{~L}^{-1} \mathrm{Na}_{2} \mathrm{~S}_{2} \mathrm{O}_{3}$ and brine, dried over anhydrous $\mathrm{Na}_{2} \mathrm{SO}_{4}$, and concentrated under reduced pressure. The crude mixture was purified by silica gel chromatography (hexane:EtOAc, 70:30, v/v) to provide the title compound 3a as a pale yellow oil, yield $160 \mathrm{mg}(57 \%)$.

Ethyl 4,5-epoxy-2-hydroxy-2-(ethoxycarbonyl)pentanoate (3b)

Colorless oil; 3 h; yield $209 \mathrm{mg}$ (90\%); IR (KBr) $\mathrm{v} / \mathrm{cm}^{-1}$ 3480, 2984, 1740, 1369, 1240, 1218, 1146, 1034, 861, 608; ${ }^{1} \mathrm{H}$ NMR (400 MHz, $\left.\mathrm{CDCl}_{3}\right) \delta 4.34-4.24$ (m, 4H), 3.14-3.09 $(\mathrm{m}, 1 \mathrm{H}), 2.76(\mathrm{t}, J 5.0 \mathrm{~Hz}, 1 \mathrm{H}), 2.53(\mathrm{dd}, J 5.0,2.8 \mathrm{~Hz}, 1 \mathrm{H})$, 2.29 (dd, $J 14.4,5.0 \mathrm{~Hz}, 1 \mathrm{H}), 2.29$ (dd, $J 14.4,6.6 \mathrm{~Hz}, 1 \mathrm{H}$ ), 1.31-1.27 (m, 6H); $\left.{ }^{13} \mathrm{C} \mathrm{NMR} \mathrm{(100} \mathrm{MHz,} \mathrm{CDCl}_{3}\right) \delta 170.1$ (C), $169.6(\mathrm{C}), 77.3(\mathrm{C}), 62.5\left(\mathrm{CH}_{2}\right), 62.3\left(\mathrm{CH}_{2}\right), 47.5\left(\mathrm{CH}_{2}\right.$ or $\mathrm{CH}), 46.7\left(\mathrm{CH}\right.$ or $\left.\mathrm{CH}_{2}\right), 37.6\left(\mathrm{CH}_{2}\right), 13.8\left(\mathrm{CH}_{3}\right), 13.7$ $\left(\mathrm{CH}_{3}\right)$; HRMS (ESI) $\mathrm{m} / z$, calcd. for $\mathrm{C}_{10} \mathrm{H}_{16} \mathrm{O}_{6} \mathrm{Na}^{+}[\mathrm{M}+\mathrm{Na}]^{+}$: 255.0839; found: 255.0839 .

\section{Diethyl 2-hydroxymalonate $(6 \mathbf{b})^{27}$}

Colorless oil; $0.5 \mathrm{~h}$; yield $58 \mathrm{mg}(33 \%)$; IR $(\mathrm{KBr}) \mathrm{v} / \mathrm{cm}^{-1}$ 3467, 2986, 1754, 1468, 1238, 1120, 1024, 861; ${ }^{1} \mathrm{H}$ NMR $\left(400 \mathrm{MHz}, \mathrm{CDCl}_{3}\right) \delta 4.71(\mathrm{~d}, J 8.2 \mathrm{~Hz}, 1 \mathrm{H}), 4.33-4.26(\mathrm{~m}$, $4 \mathrm{H}), 3.72\left(\mathrm{~d}, J 8.2 \mathrm{~Hz}, 1 \mathrm{H}\right.$, exchange with $\left.\mathrm{D}_{2} \mathrm{O}\right), 1.31(\mathrm{t}$, $J 7.2 \mathrm{~Hz}, 6 \mathrm{H}) ;{ }^{13} \mathrm{C} \mathrm{NMR}\left(100 \mathrm{MHz}, \mathrm{CDCl}_{3}\right) \delta 168.5(\mathrm{C})$, $71.6(\mathrm{CH}), 62.6\left(\mathrm{CH}_{2}\right), 14.0\left(\mathrm{CH}_{3}\right)$; HRMS (ESI) $\mathrm{m} / z$, calcd. for $\mathrm{C}_{7} \mathrm{H}_{12} \mathrm{O}_{5} \mathrm{Na}^{+}[\mathrm{M}+\mathrm{Na}]^{+}$: 199.0577; found: 199.0583 .

\section{Dibenzyl 2-hydroxymalonate $(6 \mathrm{c})^{28}$}

White solid; $2.5 \mathrm{~h}$; yield $159 \mathrm{mg}(53 \%), \mathrm{mp} 60-62{ }^{\circ} \mathrm{C}$; IR (KBr) v / $\mathrm{cm}^{-1} 3431,3037,2959,1744,1456,1342$, $1277,1169,732 ;{ }^{1} \mathrm{H}$ NMR $\left(400 \mathrm{MHz}, \mathrm{CDCl}_{3}\right) \delta 7.35-7.25$ $(\mathrm{m}, 10 \mathrm{H}), 5.23(\mathrm{~d}, J 12.2 \mathrm{~Hz}, 2 \mathrm{H}), 5.18(\mathrm{~d}, 12.2 \mathrm{~Hz}, 2 \mathrm{H})$, $4.80(\mathrm{~d}, J 8.4 \mathrm{~Hz}, 1 \mathrm{H}), 3.49$ (d, J $8.4 \mathrm{~Hz}, 1 \mathrm{H})$. Data for the cyclic bis-adduct 8 (10-20\%); ${ }^{1} \mathrm{H}$ NMR $\left(400 \mathrm{MHz}, \mathrm{CDCl}_{3}\right.$ ) $\delta$ 7.4-7.2 (m, 10H), 5.07-4.98 (m, 2H), $4.81(\mathrm{~d}, J 8.4 \mathrm{~Hz}$, $2 \mathrm{H}), 3.49(\mathrm{~d}, J 8.4 \mathrm{~Hz}, 2 \mathrm{H}) ;{ }^{13} \mathrm{C} \mathrm{NMR}\left(100 \mathrm{MHz}, \mathrm{CDCl}_{3}\right)$ $\delta 168.4(\mathrm{C}), 134.7(\mathrm{C}), 128.79(\mathrm{CH}), 128.78(\mathrm{CH}), 128.5$ $(\mathrm{CH}), 71.7(\mathrm{CH}), 68.3\left(\mathrm{CH}_{2}\right)$; HRMS (ESI) $\mathrm{m} / z$, calcd. for $\mathrm{C}_{17} \mathrm{H}_{16} \mathrm{O}_{5} \mathrm{Na}^{+}[\mathrm{M}+\mathrm{Na}]^{+}$: 323.0890; found: 323.0886 .

Methyl 5-[hydroxy(phenyl)methyl]-2-oxotetrahydrofuran3-carboxylate (11)

To a $10 \mathrm{~mL}$ glass tube containing a solution of epoxide $\mathbf{2 a}$ (264 mg, $1.0 \mathrm{mmol}$ ) in tetrahydrofuran (THF) $(2.5 \mathrm{~mL})$ was added $\mathrm{Mg}\left(\mathrm{ClO}_{4}\right)_{2}(223 \mathrm{mg}, 1.0 \mathrm{mmol})$. The vessel was sealed 
with a septum, placed into the microwave cavity, and the mixture was heated to $100{ }^{\circ} \mathrm{C}$ (maximum power $=100 \mathrm{~W}$ ) under stirring for $1 \mathrm{~h}$. After cooling to $25^{\circ} \mathrm{C}$, the mixture was diluted with EtOAc and washed with water. The aqueous phase was extracted with EtOAc and the combined organic layers were washed with $0.1 \mathrm{~mol} \mathrm{~L}^{-1} \mathrm{HCl}$ and brine, dried over anhydrous $\mathrm{Na}_{2} \mathrm{SO}_{4}$, and concentrated under reduced pressure to furnish a yellow oil. The crude product was purified by silica gel chromatography (hexane:EtOAc, 70:30, $\mathrm{v} / \mathrm{v}$ ) to provide the title compound $\mathbf{1 1}$ (yellow oil, $110 \mathrm{mg}$, $44 \%$ ) as a 2:1 mixture of diastereoisomers (11a:11b).

\section{Isomer 11a (major)}

IR (2:1 mixture) (KBr) $v / \mathrm{cm}^{-1} 3496,3031,2955,1779$, 1738, 1452, 1163, 1026, 757, 706; ' $\mathrm{H}$ NMR (400 MHz, $\left.\mathrm{CDCl}_{3}\right) \delta$ 7.37-7.29 (m, 5H), $5.10(\mathrm{~d}, J 2.6 \mathrm{~Hz}, 1 \mathrm{H}), 4.77$ (ddd, $J$ 8.0, 4.6, $2.6 \mathrm{~Hz}, 1 \mathrm{H}), 3.82-3.73(\mathrm{~m}, 1 \mathrm{H}), 3.72$ (s, $3 \mathrm{H}), 2.48(\mathrm{ddd}, J 13.5,10.0,4.6 \mathrm{~Hz}, 1 \mathrm{H}), 2.31$ (dt, $J 13.5$, $8.0 \mathrm{~Hz}, 1 \mathrm{H}) ;{ }^{13} \mathrm{C}$ NMR $\left(100 \mathrm{MHz}, \mathrm{CDCl}_{3}\right) \delta 173.0(\mathrm{C})$, $168.7(\mathrm{C}), 138.5(\mathrm{C}), 128.6(2 \times \mathrm{CH}), 128.0(\mathrm{CH}), 126.0$ $(2 \times \mathrm{CH}), 82.6(\mathrm{CH}), 73.1(\mathrm{CH}), 53.0\left(\mathrm{CH}_{3}\right), 46.7(\mathrm{CH})$, $24.9\left(\mathrm{CH}_{2}\right)$.

\section{Isomer 11b (minor)}

${ }^{1} \mathrm{H}$ NMR (400 MHz, $\left.\mathrm{CDCl}_{3}\right) \delta$ 7.37-7.29 (m, 5H), 5.07 (d, $J 3.8 \mathrm{~Hz}, 1 \mathrm{H}), 4.59$ (ddd, $J$ 8.8, 6.6, $3.8 \mathrm{~Hz}, 1 \mathrm{H}$ ), 3.76 (s, 3H), $3.57(\mathrm{t}, J 9.8 \mathrm{~Hz}, 1 \mathrm{H}), 2.79-2.70(\mathrm{~m}, 1 \mathrm{H}), 2.17$ (ddd, $J$ 13.2, 9.8, $6.6 \mathrm{~Hz}, 1 \mathrm{H}) ;{ }^{13} \mathrm{C}$ NMR $\left(100 \mathrm{MHz}, \mathrm{CDCl}_{3}\right.$ ) $\delta 172.2$ (C), $168.3(\mathrm{C}), 138.5(\mathrm{C}), 128.5(2 \times \mathrm{CH}), 128.1$ $(\mathrm{CH}), 126.1(2 \mathrm{CH}), 82.1(\mathrm{CH}), 72.4(\mathrm{CH}), 53.1\left(\mathrm{CH}_{3}\right), 46.6$ (CH), $25.3\left(\mathrm{CH}_{2}\right)$; HRMS (2:1 mixture) (ESI) $\mathrm{m} / z$, calcd. for $\mathrm{C}_{13} \mathrm{H}_{14} \mathrm{O}_{5} \mathrm{Na}^{+}[\mathrm{M}+\mathrm{Na}]^{+}$: 273.0733; found: 273.0731.

Methyl 3-hydroxy-5-[hydroxy(phenyl)methyl]-2-oxotetrahydrofuran-3-carboxylate (12)

Obtained from lactone $\mathbf{1 1}$ (250 mg, $1.0 \mathrm{mmol})$ through the general procedure for $\alpha$-hydroxylation $(1.5 \mathrm{~h})$ as a pale yellow oil, yield $125 \mathrm{mg}(47 \%)$ as a 2:1 mixture of diastereoisomers (12a:12b).

\section{Isomer 12a (major)}

IR (2:1 mixture) $(\mathrm{KBr}) \vee / \mathrm{cm}^{-1} 3459,2957,1783$, 1750, 1452, 1265, 1207, 1024, 704; ${ }^{1} \mathrm{H}$ NMR (400 MHz, $\left.\mathrm{CDCl}_{3}\right) \delta$ 7.39-7.33 (m, 5H), 5.19 (d, J 3.6 Hz, $\left.1 \mathrm{H}\right), 4.80$ (ddd, $J$ 8.4, 6.8, 3.6 Hz, 1H), 4.27 (br s, $1 \mathrm{H}$ ), 3.83 (s, 3H), $2.63(\mathrm{dd}, J 13.8,8.4 \mathrm{~Hz}, 1 \mathrm{H}), 2.41(\mathrm{dd}, J 13.8,6.8 \mathrm{~Hz}$, $1 \mathrm{H}) ;{ }^{13} \mathrm{C}$ NMR $\left(100 \mathrm{MHz}, \mathrm{CDCl}_{3}\right) \delta 173.1(\mathrm{C}), 170.2(\mathrm{C})$, $137.9(\mathrm{C}), 128.9(2 \times \mathrm{CH}), 128.5(\mathrm{CH}), 126.1(2 \times \mathrm{CH})$, $80.9(\mathrm{CH}), 77.2(\mathrm{C}), 72.4(\mathrm{CH}), 54.1\left(\mathrm{CH}_{3}\right), 33.4\left(\mathrm{CH}_{2}\right)$.
Isomer 12b (minor)

${ }^{1} \mathrm{H}$ NMR (400 MHz, $\mathrm{CDCl}_{3}$ ) $\delta$ 7.39-7.33 (m, 5H), 5.21 (d, $J 3.6 \mathrm{~Hz}, 1 \mathrm{H}$ ), 4.89 (ddd, $J$ 9.4, $5.8,3.6 \mathrm{~Hz}, 1 \mathrm{H}$ ), 4.08 (br s, 1H), 3.89 (s, 3H), 2.95 (dd, $J 13.6,9.4 \mathrm{~Hz}, 1 \mathrm{H}), 2.02$ (dd, $J$ 13.6, $5.8 \mathrm{~Hz}, 1 \mathrm{H}) ;{ }^{13} \mathrm{C} \mathrm{NMR}\left(100 \mathrm{MHz}, \mathrm{CDCl}_{3}\right)$ $\delta 172.6(\mathrm{C}), 170.6(\mathrm{C}), 137.8(\mathrm{C}), 128.8(2 \times \mathrm{CH}), 128.5$ $(\mathrm{CH}), 126.1(2 \times \mathrm{CH}), 82.2(\mathrm{CH}), 77.4(\mathrm{C}), 72.0(\mathrm{CH}), 54.2$ $\left(\mathrm{CH}_{3}\right), 33.5\left(\mathrm{CH}_{2}\right)$; HRMS (2:1 mixture) (ESI) $\mathrm{m} / 2$, calcd. for $\mathrm{C}_{13} \mathrm{H}_{14} \mathrm{O}_{6} \mathrm{Na}^{+}$[M $\left.+\mathrm{Na}\right]^{+}: 289.0683$; found: 289.0682 .

Methyl 5-benzyl-3-hydroxy-2-oxotetrahydrofuran3-carboxylate $(\mathbf{1 6})^{29}$

\section{From $\gamma$-hydroxy malonate 14}

To a $10 \mathrm{~mL}$ glass tube containing a solution of alcohol $\mathbf{1 4}^{19}$ (266 mg, $\left.1.0 \mathrm{mmol}\right)$ in THF $(3.5 \mathrm{~mL})$ was added $\mathrm{Mg}\left(\mathrm{ClO}_{4}\right)_{2}(223 \mathrm{mg}, 1.0 \mathrm{mmol})$. The vessel was sealed with a septum, placed into the microwave cavity, and the mixture was heated to $100{ }^{\circ} \mathrm{C}$ (maximum power $=100 \mathrm{~W}$ ) under stirring for $1 \mathrm{~h}$. After cooling to $25^{\circ} \mathrm{C}$, the mixture was diluted with EtOAc and washed with water. The aqueous phase was extracted with EtOAc and the combined organic layers were washed with $0.1 \mathrm{~mol} \mathrm{~L}^{-1} \mathrm{HCl}$ and brine, dried over anhydrous $\mathrm{Na}_{2} \mathrm{SO}_{4}$, and concentrated under reduced pressure to provide methyl 5-benzyl-2-oxotetrahydrofuran3-carboxylate (15, pale yellow oil, $203 \mathrm{mg}, 87 \%$ ) as a ca. 1.1:1 mixture of diastereoisomers, which was used in the next step without further purification.

Methyl 5-benzyl-2-oxotetrahydrofuran-3-carboxylate (15)

IR $(\mathrm{KBr}) \mathrm{v} / \mathrm{cm}^{-1} 3029,2953,1781,1738,1438,1356$, 1163, 1016, 704; ${ }^{1} \mathrm{H}$ NMR $\left(200 \mathrm{MHz}, \mathrm{CDCl}_{3}\right) \delta$ 7.36-7.20 (m, 10H), 4.98-4.85 (m, 1H), 4.72-4.58 (m, 1H), $3.79(\mathrm{~s}$, $3 \mathrm{H}), 3.74$ (s, 3H), 3.62 (dd, J 10.8, $9.4 \mathrm{~Hz}, 1 \mathrm{H}), 3.34$ (dd, $J$ 9.4, $5.4 \mathrm{~Hz}, 1 \mathrm{H}), 3.17$ (dd, $J 13.6,6.6 \mathrm{~Hz}, 1 \mathrm{H}), 3.01-2.91$ (m, 3H), 2.63 (ddd, $J 13.4,7.0,5.6 \mathrm{~Hz}, 1 \mathrm{H}$ ), 2.48-2.37 (m, 2H), 2.20 (ddd, $J 13.4,9.6,6.8 \mathrm{~Hz}, 1 \mathrm{H}$ ); ${ }^{13} \mathrm{C}$ NMR $\left(100 \mathrm{MHz}, \mathrm{CDCl}_{3}\right) \delta 171.7$ (C), $171.5(\mathrm{C}), 168.28$ (C), 168.26 (C), 135.7 (C), 135.3 (C), $129.7(2 \times \mathrm{CH}), 129.4$ $(2 \times \mathrm{CH}), 128.9(2 \times \mathrm{CH}), 128.8(2 \times \mathrm{CH}), 127.3(\mathrm{CH})$, $127.2(\mathrm{CH}), 80.0(\mathrm{CH}), 79.9(\mathrm{CH}), 53.2\left(2 \times \mathrm{CH}_{3}\right), 47.2$ $(\mathrm{CH}), 46.7(\mathrm{CH}), 41.4\left(\mathrm{CH}_{2}\right), 41.2\left(\mathrm{CH}_{2}\right), 31.8\left(\mathrm{CH}_{2}\right), 31.1$ $\left(\mathrm{CH}_{2}\right)$.

$\alpha$-Hydroxylation of lactone 15 prepared above (203 mg, $0.87 \mathrm{mmol}$ ) was achieved through the general procedure $(1.5 \mathrm{~h})$ to give a pale yellow oil, yield $127 \mathrm{mg}(76 \%)$ as a 3:1 mixture of diastereoisomers (16-syn:16-anti).

\section{Isomer 16-syn (major)}

IR (3:1 mixture) $(\mathrm{KBr}) v / \mathrm{cm}^{-1} 3467,3029,2955,1781$, 1748, 1438, 1283, 1195, 1010, 704; ${ }^{1} \mathrm{H}$ NMR $(400 \mathrm{MHz}$, 
$\left.\mathrm{CDCl}_{3}\right) \delta$ 7.35-7.22 (m, 5H), 4.98-4.90 (m, 1H), 4.08 (br s, $1 \mathrm{H}), 3.85$ (s, 3H), 3.19 (dd, $J 14.4,6.6 \mathrm{~Hz}, 1 \mathrm{H}), 2.97$ (dd, $J 14.4,6.6 \mathrm{~Hz}, 1 \mathrm{H}), 2.51(\mathrm{dd}, J 13.6,8.8 \mathrm{~Hz}, 1 \mathrm{H}), 2.38(\mathrm{dd}$, $J$ 13.6, $6.0 \mathrm{~Hz}, 1 \mathrm{H}) ;{ }^{13} \mathrm{C}$ NMR $\left(100 \mathrm{MHz}, \mathrm{CDCl}_{3}\right) \delta 172.5$ (C), $170.6(\mathrm{C}), 135.5(\mathrm{C}), 129.4(2 \times \mathrm{CH}), 128.8(2 \times \mathrm{CH})$, 127.2 (CH), $79.7(\mathrm{CH}), 77.4(\mathrm{C}), 54.0\left(\mathrm{CH}_{3}\right), 41.0\left(\mathrm{CH}_{2}\right)$, $39.6\left(\mathrm{CH}_{2}\right)$.

\section{Isomer 16-anti (minor)}

${ }^{1} \mathrm{H}$ NMR $\left(400 \mathrm{MHz}, \mathrm{CDCl}_{3}\right) \delta$ 7.35-7.22 (m, 5H), 4.90-4.81 (m, 1H), 4.05 (br s, 1H), $3.83(\mathrm{~s}, 3 \mathrm{H}), 3.18(\mathrm{dd}$, $J$ 14.0, 6.6 Hz, 1H), $2.96(\mathrm{dd}, J 14.0,6.6 \mathrm{~Hz}, 1 \mathrm{H}), 2.73$ (dd, $J 13.6,6.0 \mathrm{~Hz}, 1 \mathrm{H}), 2.22(\mathrm{dd}, J 13.6,9.0 \mathrm{~Hz}, 1 \mathrm{H}) ;{ }^{13} \mathrm{C} \mathrm{NMR}$ $\left(100 \mathrm{MHz}, \mathrm{CDCl}_{3}\right) \delta 172.9(\mathrm{C}), 170.3(\mathrm{C}), 135.5(\mathrm{C}), 129.5$ $(2 \times \mathrm{CH}), 128.9(2 \times \mathrm{CH}), 127.3(\mathrm{CH}), 78.6(\mathrm{CH}), 77.3(\mathrm{C})$, $54.1\left(\mathrm{CH}_{3}\right), 41.6\left(\mathrm{CH}_{2}\right), 39.6\left(\mathrm{CH}_{2}\right)$; HRMS (3:1 mixture) (ESI) $\mathrm{m} / z$, calcd. for $\mathrm{C}_{13} \mathrm{H}_{14} \mathrm{O}_{5} \mathrm{Na}^{+}[\mathrm{M}+\mathrm{Na}]^{+}:$273.0733; found: 273.0732 .

\section{From the $\alpha$-hydroxylated epoxide $\mathbf{3 a}$}

To a round-bottomed flask containing the $\alpha$-hydroxylated epoxide 3a (280 mg, $1.0 \mathrm{mmol})$ and THF (10 mL), under magnetic stirring, was added Pd/C 10\% (28 mg, 10\% $\mathrm{m} / \mathrm{m}$ ), then the system was charged with $\mathrm{H}_{2}$ (balloon) and the mixture was stirred at $25^{\circ} \mathrm{C}$ for $4 \mathrm{~h}$. Next, the reaction mixture was filtered through a Celite pad and the filter cake was exhaustively washed with $\mathrm{MeOH}$. The filtrate was concentrated under reduced pressure to provide the title compound $\mathbf{1 6}$ (pale yellow oil, $118 \mathrm{mg}, \mathbf{4 7 \%}$ ), as a 1.7:1 mixture of diastereoisomers (16-syn:16-anti). Spectroscopic data are in fully agreement with the same product $\mathbf{1 6}$ prepared from $\alpha$-hydroxylation of lactone $\mathbf{1 5}$ as described above.

General procedure for the decarboxylation of lactones 12 and 16

To a $10 \mathrm{~mL}$ glass tube containing a solution of lactone 12 or $16(1.0 \mathrm{mmol})$ in dimethylformamide (DMF) (3.5 mL) was added $\mathrm{LiCl}(42 \mathrm{mg}, 1.0 \mathrm{mmol})$. The vessel was sealed with a septum, placed into the microwave cavity, and the mixture was heated to $130{ }^{\circ} \mathrm{C}$ (maximum power $=100 \mathrm{~W}$ ) under stirring for $30 \mathrm{~min}$. After cooling to $25^{\circ} \mathrm{C}$, the mixture was diluted with EtOAc and washed with water. The aqueous phase was extracted with EtOAc and the combined organic layers were washed with $0.1 \mathrm{~mol} \mathrm{~L}^{-1} \mathrm{HCl}$ and brine, dried over anhydrous $\mathrm{Na}_{2} \mathrm{SO}_{4}$, and concentrated under reduced pressure. The crude product was purified by silica gel chromatography (hexane:EtOAc, 70:30, v/v).
3-Hydroxy-5-[hydroxy(phenyl)methyl]dihydrofuran2(3H)-one (13) ${ }^{26}$

Orange oil, obtained as a mixture of two diastereoisomers. After careful separation by column chromatography, each epimer was isolated and properly characterized.

\section{Isomer 13-syn}

Orange oil; yield $21 \mathrm{mg}(10 \%)$; RF $=0.30$ (hexane:EtOAc, 50:50, v/v); IR (KBr) v/ $\mathrm{cm}^{-1} 3512,3398,2956,1764,1734$, 1450, 1209, 1114, 1003, 720, 702; ${ }^{\mathrm{H}} \mathrm{H}$ NMR (400 MHz, $\left.\mathrm{CDCl}_{3}\right) \delta$ 7.36-7.26 (m, 5H), $5.08(\mathrm{~d}, J 2.0 \mathrm{~Hz}, 1 \mathrm{H}), 4.73$ (dt, $J 8.8,2.0 \mathrm{~Hz}, 1 \mathrm{H}), 4.67(\mathrm{t}, J 8.8 \mathrm{~Hz}, 1 \mathrm{H}), 2.57-2.51(\mathrm{~m}$, $1 \mathrm{H}), 1.95$ (dt, $J 13.5,8.8 \mathrm{~Hz}, 1 \mathrm{H}) ;{ }^{13} \mathrm{C}$ NMR $(100 \mathrm{MHz}$, $\left.\mathrm{CDCl}_{3}\right) \delta 179.2(\mathrm{C}), 138.5(\mathrm{C}), 128.8(2 \times \mathrm{CH}), 128.2(\mathrm{CH})$, $126.0(2 \times \mathrm{CH}), 81.7(\mathrm{CH}), 73.6(\mathrm{CH}), 67.5(\mathrm{CH}), 29.5$ $\left(\mathrm{CH}_{2}\right)$; HRMS (ESI) $\mathrm{m} / z$, calcd. for $\mathrm{C}_{11} \mathrm{H}_{12} \mathrm{O}_{4} \mathrm{Na}^{+}[\mathrm{M}+\mathrm{Na}]^{+}$: 231.0628; found: 231.0626 .

\section{Isomer 13-anti}

Orange oil; yield $29 \mathrm{mg}(14 \%) ; \mathrm{RF}=0.15$ (hexane:EtOAc, 50:50, v/v); IR (KBr) v / $\mathrm{cm}^{-1} 3406$, 3064, 1777, 1452, 1326, 1203, 1126, 1008, 704; ' ${ }^{\mathrm{H}} \mathrm{NMR}$ $\left(400 \mathrm{MHz}, \mathrm{CDCl}_{3}\right) \delta 7.34-7.26(\mathrm{~m}, 5 \mathrm{H}), 5.13(\mathrm{~d}, J 3.0 \mathrm{~Hz}$, $1 \mathrm{H}) 4.56$ (ddd, $J 9.6,8.0,3.0 \mathrm{~Hz}, 1 \mathrm{H}), 4.40(\mathrm{t}, J 8.8 \mathrm{~Hz}, 1 \mathrm{H})$, 4.28 (br s, 1H), 2.29-2.17 (m, 2H); ${ }^{13} \mathrm{C}$ NMR $(100 \mathrm{MHz}$, $\left.\mathrm{CDCl}_{3}\right) \delta 177.9(\mathrm{C}), 138.1(\mathrm{C}), 128.7(2 \times \mathrm{CH}), 128.2(\mathrm{CH})$, $126.1(2 \times \mathrm{CH}), 80.8(\mathrm{CH}), 72.2(\mathrm{CH}), 68.2(\mathrm{CH}), 29.6$ $\left(\mathrm{CH}_{2}\right)$; HRMS (ESI) $\mathrm{m} / z$, calcd. for $\mathrm{C}_{11} \mathrm{H}_{12} \mathrm{O}_{4} \mathrm{Na}^{+}[\mathrm{M}+\mathrm{Na}]^{+}$: 231.0628; found: 231.0629 .

\section{3-Hydroxy-5-benzyldihydrofuran-2-one (4) (30 $^{30}$}

Orange oil; yield $136 \mathrm{mg}$ (71\%), obtained as a 3:1 mixture of the 4-syn and 4-anti isomers. After chromatography, each diastereoisomer was isolated and properly characterized.

\section{Isomer 4-syn}

White solid; yield $69 \mathrm{mg}(36 \%)$; mp $70-72{ }^{\circ} \mathrm{C}$; $\mathrm{RF}=0.36$ (hexane:EtOAc, 50:50, v/v); IR (3:1 mixture) $(\mathrm{KBr}) \mathrm{v} / \mathrm{cm}^{-1} 3406,2925,1774,1454,1195,1126,991$, 702; ${ }^{1} \mathrm{H}$ NMR $\left(400 \mathrm{MHz}, \mathrm{CDCl}_{3}\right) \delta$ 7.33-7.20 (m, 5H), 4.604.49 (m, 2H), 3.88 (br s, $1 \mathrm{H}), 3.11$ (dd, $J 14.0,6.4 \mathrm{~Hz}, 1 \mathrm{H})$, $2.93(\mathrm{dd}, J 14.0,6.4 \mathrm{~Hz}, 1 \mathrm{H}), 2.59(\mathrm{ddd}, J 13.2,8.4,5.2 \mathrm{~Hz}$, $1 \mathrm{H}), 2.00-1.91(\mathrm{~m}, 1 \mathrm{H}) ;{ }^{13} \mathrm{C} \mathrm{NMR}\left(100 \mathrm{MHz}, \mathrm{CDCl}_{3}\right) \delta$ $177.8(\mathrm{C}), 135.6(\mathrm{C}), 129.4(2 \times \mathrm{CH}), 128.8(2 \times \mathrm{CH}), 127.2$ $(\mathrm{CH}), 77.5(\mathrm{CH}), 68.6(\mathrm{CH}), 41.3\left(\mathrm{CH}_{2}\right), 36.7\left(\mathrm{CH}_{2}\right)$; HRMS (ESI) $m / z$, calcd. for $\mathrm{C}_{11} \mathrm{H}_{12} \mathrm{O}_{3} \mathrm{Na}^{+}[\mathrm{M}+\mathrm{Na}]^{+}: 215.0679$; found: 215.0677 .

\section{Isomer 4-anti}

Orange oil; yield $25 \mathrm{mg}(13 \%) ; \mathrm{RF}=0.42$ 
(hexane:EtOAc, 50:50, v/v); ${ }^{1} \mathrm{H}$ NMR (200 MHz, $\left.\mathrm{CDCl}_{3}\right)$ $\delta$ 7.35-7.17 (m, 5H), 4.96-4.85 (m, 1H), $4.03(\mathrm{t}, J 7.8 \mathrm{~Hz}$, 1H), 3.18 (br s, 1H), 2.97 (d, J 5.8 Hz, 2H), 2.36-2.19 (m, $2 \mathrm{H}) ;{ }^{13} \mathrm{C}$ NMR $\left(50 \mathrm{MHz}, \mathrm{CDCl}_{3}\right) \delta 177.6(\mathrm{C}), 135.4(\mathrm{C})$, $129.7(2 \times \mathrm{CH}), 128.9(2 \times \mathrm{CH}), 127.4(\mathrm{CH}), 78.5(\mathrm{CH})$, $67.2(\mathrm{CH}), 41.3\left(\mathrm{CH}_{2}\right), 34.6\left(\mathrm{CH}_{2}\right)$; HRMS (ESI) $\mathrm{m} / \mathrm{z}$, calcd. for $\mathrm{C}_{11} \mathrm{H}_{12} \mathrm{O}_{3} \mathrm{Na}^{+}[\mathrm{M}+\mathrm{Na}]^{+}$: 215.0679; found: 215.0678.

\section{Supplementary Information}

Supplementary information $\left({ }^{1} \mathrm{H}\right.$ and ${ }^{13} \mathrm{C}$ NMR spectra) is available free of charge at http://jbcs.sbq.org.br as PDF file.

\section{Acknowledgments}

We are grateful to the Central de Análises de Química (UFSC) for the spectroscopic analysis. Special thanks are due to CEBIME (Laboratório Central de Biologia Molecular e Estrutural, UFSC) for providing the mass spectra. The authors are grateful to CAPES (Coordenação de Aperfeiçoamento de Pessoal de Nível Superior) and $\mathrm{CNPq}$ (Conselho Nacional de Desenvolvimento Científico e Tecnológico) for fellowships. Support from INCTCatalysis (Brazilian Research Council) is also gratefully acknowledged.

\section{References}

1. Christoffers, J.; Baro, A.; Werner, T.; Adv. Synth. Catal. 2004, 346, 143.

2. Reddy, D. S.; Shibata, N.; Nagai, J.; Nakamura, S.; Toru, T.; Angew. Chem., Int. Ed. 2009, 48, 803.

3. Terent'ev, A. O.; Vil, V. A.; Gorlov, E. S.; Nikishin, G. I.; Pivnitsky, K. K.; Adam, W.; J. Org. Chem. 2016, 81, 810.

4. Feng, Y.; Huang, R.; Hua, L.; Xiong, Y.; Coeffard, V.; Synthesis 2016, 48, 2637.

5. Asahara, H.; Nishiwaki, N.; J. Org. Chem. 2014, 79, 11735.

6. Davis, F. A.; Liu, H.; Chen, B.-C.; Zhou, P.; Tetrahedron 1998, $54,10481$.

7. Li, Z.; Li, T.; Li, J.; He, L.; Jia, X.; Yang, J.; Synlett 2015, 26, 2863.
8. Miao, C.-B.; Wang, Y.-H.; Xing, M.-L.; Lu, X.-W.; Sun, X.-Q.; Yang, H.-T.; J. Org. Chem. 2013, 78, 11584.

9. Chuang, G. J.; Wang, W.; Lee, E.; Ritter, T.; J. Am. Chem. Soc. 2011, 133, 1760 .

10. Monguchi, Y.; Takahashi, T.; Iida, Y.; Fujiwara, Y.; Inagaki, Y.; Maegawa, T.; Sajiki, H.; Synlett 2008, 2291.

11. Christoffers, J.; Werner, T.; Unger, S.; Frey, W.; Eur. J. Org. Chem. 2003, 425.

12. Chen, B.-C.; Zhou, P.; Davis, F. A.; Ciganek, E.; Org. React. 2003, 62, DOI: 10.1002/0471264180.or062.01.

13. Sasamoto, N.; Dubs, C.; Hamashima, Y.; Sodeoka, M.; J. Am. Chem. Soc. 2006, 128, 14010.

14. Adam, W.; Mijller, M.; Prechtl, F.; J. Org. Chem. 1994, 59, 2358.

15. Adam, W.; Smerz, A. K.; Tetrahedron 1996, 52, 5799.

16. Yu, J.; Cui, J.; Zhang, C.; Eur. J. Org. Chem. 2010, 7020.

17. Stergiou, A.; Bariotaki, A.; Kalaitzakis, D.; Smonou, I.; J. Org. Chem. 2013, 78, 7268.

18. Marques, M. V.; Sá, M. M.; J. Org. Chem. 2014, 79, 4650.

19. Oliveira, C. C.; Marques, M. V.; Godoi, M. N.; Regiani, T.; Santos, V. G.; Santos, E. A. F.; Eberlin, M. N.; Sá, M. M.; Correia, C. R. D.; Org. Lett. 2014, 16, 5180.

20. Amagata, T.; Usami, Y.; Minoura, K.; Ito, T.; Numata, A.; J. Antibiot. 1998, 51, 33.

21. Pawar, V. U.; Ghosh, S.; Chopade, B. A.; Shinde, V. S.; Bioorg. Med. Chem. Lett. 2010, 20, 7243.

22. Kumar, D. N.; Reddy, C. R.; Das, B.; Synthesis 2011, 19, 3190.

23. Sabitha, G.; Srinivas, R.; Das, S. K.; Yadav, J. S.; Beilstein J. Org. Chem. 2010, 6, DOI: 10.3762/bjoc.6.8.

24. Shu, C.; Liu, M.; Sun, Y.; Ye, L.; Org. Lett. 2012, 4, 4958.

25. Hashimoto, N.; Kanda, A.; Org. Process Res. Dev. 2002, 6, 405.

26. Antoniotti, S.; Duñach, E.; Tetrahedron Lett. 2009, 50, 2536.

27. Companyó, X.; Mazzanti, A.; Moyano A.; Janecka, A.; Rios, R.; Chem. Commun. 2013, 49, 1184.

28. Kurz, T.; Geffken, D.; Z. Naturforsch. B 1999, 54b, 667.

29. Achmatowicz, O.; Bialecka-Florjańczyk, E.; Tetrahedron 1996, 52,8827 .

30. Kumar, A. N.; Bhatt, S.; Chattopadhyay, S.; Tetrahedron: Asymmetry 2009, 20, 205.

Submitted: February 4, 2019

Published online: May 7, 2019 